\title{
AMARISOLIDE A AND PEDALITIN AS BIOACTIVE COMPOUNDS IN THE ANTINOCICEPTIVE EFFECTS OF SALVIA CIRCINATA (LAMIACEAE)
}

\author{
AMARISÓLIDA A Y PEDALITINA COMO COMPUESTOS BIOACTIVOS EN EL EFECTO \\ ANTINOCICEPTIVO DE SALVIA CIRCINATA (LAMIACEAE)
}

\author{
Gabriel Fernando Moreno-Pérez ${ }^{1}$, María Eva González-Trujano², Martha Juana Martínez-Gordillo³, \\ Rubén San Miguel-Chávez ${ }^{4}$, Francisco Alberto Basurto-Peña ${ }^{5}$, Alejandro Dorazco-González ${ }^{6}$, and Eva \\ AGUIRRE-HERNÁNDEZ ${ }^{1 *}$
}

\author{
${ }^{1}$ Laboratorio de Fitoquímica, Departamento de Ecología y Recursos Naturales. Facultad de Ciencias, Universidad Nacional \\ Autónoma de México, Ciudad Universitaria, Ciudad de México, México. \\ ${ }^{2}$ Laboratorio de Neurofarmacología de Productos Naturales. Dirección de Investigaciones en Neurociencias del Instituto Nacional \\ de Psiquiatría Ramón de la Fuente Muñiz, Ciudad de México, México. \\ ${ }^{3}$ Departamento de Biología Comparada. Universidad Nacional Autónoma de México, Ciudad Universitaria, Ciudad de México, \\ México. \\ ${ }^{4}$ Posgrado en Botánica, Laboratorio de Fitoquímica, Colegio de Postgraduados, Texcoco Estado de México, México. \\ 5 Jardín Botánico. Instituto de Biología, Universidad Nacional Autónoma de México, Ciudad Universitaria, Ciudad de México, \\ México. \\ ${ }^{6}$ Instituto de Química, Universidad Nacional Autónoma de México, Circuito Exterior, Ciudad Universitaria, Ciudad de México, \\ México.
}

*Corresponding author: eva_aguirre@ciencias.unam.mx

\begin{abstract}
Background: Salvia circinata is an endemic species of Mexico used in the folk medicine of Santiago Huauclilla, Oaxaca, mainly as remedy for gastrointestinal diseases.

Hypothesis: If the extracts of Salvia circinata have secondary metabolites with antinociceptive activity, then the behavior of nociception in the model of "whriting" in mice will decrease.

Specie studied: Salvia circinata Cav. (Lamiaceae).

Study site and years of study: Salvia circinata was collected in Santiago Huauclilla, Oaxaca, in July 2014.

Methods: Firstly, the acute toxicity of $S$. circinata extracts was evaluated to calculate the $\mathrm{LD}_{50}$ with OECD method. Then, dose-response curves of the antinociceptive effect of $S$. circinata organic and aqueous extracts $(1,10,30,100$, and $300 \mathrm{mg} / \mathrm{kg})$ were obtained in the writhing test in mice. Furthermore, chromatographic techniques were applied to isolate the compounds and were identified by comparison of the values of ${ }^{1} \mathrm{H} \mathrm{NMR},{ }^{13} \mathrm{C}$ NMR and ESIMS reported in the literature.

Results: Our data showed significant antinociceptive activity in all the tested extracts. Amarisolide A and pedalitin were isolated in the ethyl acetate and methanol extracts, respectively and assayed at doses of 1,5 and $10 \mathrm{mg} / \mathrm{kg}$, i.p. All the compounds decreased nociception in mice in at least $50 \%$ from a minimal dosage of $1 \mathrm{mg} / \mathrm{kg}$, i.p. and in a similar manner than the reference drug ketorolac (1 mg/kg, i.p.).

Conclusions: Our findings give evidence that Salvia circinata possesses antinociceptive activity depending on the presence of several known bioactive constituents, reinforcing its use in the Mexican traditional medicine to alleviate abdominal pain.
\end{abstract}

Key words: Abdominal pain, amarisolide A, Lamiaceae, pedalitin, Salvia circinata.

\section{Resumen}

Antecedentes: Salvia circinata es una especie endémica de México, utilizada en Santiago Huauclilla, Oaxaca como remedio para enfermedades gastrointestinales.

Hipótesis: Si los extractos de Salvia circinata tienen metabolitos con actividad antinociceptiva, entonces disminuirán la conducta nociceptiva en el modelo writhing.

Especie estudiada: Salvia circinata Cav. (Lamiaceae).

Lugar de estudio y años de estudio: Salvia circinata se colectó en Santiago Huauclilla, Oaxaca, en julio de 2014.

Métodos: Se evaluó la toxicidad aguda $\left(\mathrm{DL}_{50}\right)$ de los extractos de $S$. circinata mediante el método de la OECD. Se realizaron las curvas dosis-respuesta del efecto antinociceptivo de los extractos de $S$. circinata $(1,10,30,100$, and $300 \mathrm{mg} / \mathrm{kg})$ en el modelo de writhing en ratones. Además, se utilizaron técnicas cromatográficas para aislar los compuestos y se identificaron por comparación de los datos de ${ }^{1} \mathrm{H} R M N$, ${ }^{13} \mathrm{C}$ RMN y ESIMS reportados en la literatura.

Resultados: Nuestros resultados muestran una actividad antinociceptiva significativa en todos los extractos evaluados. La amarisólida A y la pedalitina fueron aisladas de los extractos de acetato de etilo y metanol, respectivamente y evaluadas a dosis de $1,5 \mathrm{y} 10 \mathrm{mg} / \mathrm{kg}$, i.p. Todos

This is an open access article distributed under the terms of the Creative Commons Attribution License CCBY-NC (4.0) international. https://creativecommons.org/licences/by-nc/4.0/ 
los compuestos disminuyeron la nocicepción en los ratones en al menos el $50 \%$ a partir de una dosis mínima de $1 \mathrm{mg} / \mathrm{kg}$, i.p. y de manera similar al ketorolaco ( $1 \mathrm{mg} / \mathrm{kg}$, i.p.).

Conclusiones: Nuestros hallazgos dan evidencia de que Salvia circinata posee actividad antinociceptiva debido a varios constituyentes bioactivos conocidos, con ello se refuerza su uso en la medicina tradicional mexicana para el alivio del dolor abdominal.

Palabras clave: Dolor abdominal, amarisólida A, Lamiaceae, pedalitina, Salvia circinata.

Salvia circinata Cav. (syn. Salvia amarissima Ortega) is an endemic herbaceous plant widely distributed in Mexico (Martínez-Gordillo et al. 2013). In Santiago Huauclilla, Oaxaca, a Mexican region where traditional medicine using plants is extensively common, this plant is known as "bretónica", and according to the citizens it is frequently used as an infusion for its analgesic and anti-inflammatory properties mainly to alleviate gastrointestinal illness that includes diarrhea and stomachache (Nambo 2015) and for the treatment of ulcers and diabetes (Castro et al. 2014, Flores-Bocanegra et al. 2017).

Phytochemical studies of $S$. circinata have reported the presence of diterpenoids such as amarissinins A-E (Bautista et al. 2016, Fragoso-Serrano et al. 2019) and teotihuacanin (Bautista et al. 2015, Fragoso-Serrano et al. 2019), and glucoside diterpenoids as amarisolides A-F (Maldonado et al. 1996, Flores-Bocanegra et al. 2017, Fragoso-Serrano et al. 2019). Flavonoids like pedalitin (Maldonado et al. 1996), apigenin-7-O- $\beta$-D-glucoside, the flavone 2-(3,4-dimethoxyphenyl)-5,6-dihydroxy-7-methoxy-4H-chromen-4-one, and new biflavone (Flores-Bocanegra et al. 2017).

Pharmacological studies have reported the cytotoxic effect of teotihuacanin isolated from S. amarissima as potent compound with multidrug resistance (MDR) modulatory activity in the vinblastine-resistant MCF-7 cancer cell line (Bautista et al. 2015). Cytotoxicity of the amarissinins has been also reported against five human cancer cell lines, as well as MDR modulatory activity in a breast cancer cell line (MCF-7) resistant to vinblastine (Bautista et al. 2016). In addition, the in vivo antihyperglycemic activity and the $\alpha$-glucosidase in vitro inhibitory effects have been reported for the extract of $S$. circinata aerial parts and its flavonoids and clerodane diterpene glucosides (Flores-Bocanegra et al. 2017). However, scientific studies supporting the efficacy and security of the use of this plant for abdominal pain are lacking, so in this study we explore the acute toxicity in mice following the OECD (2001) and the pharmacological evidence of the antinociceptive activity of $S$. circinata and bioactive compounds evaluating extracts from different polarity in an abdominal pain model.

\section{Material and methods}

Plant material. Salvia circinata aerial parts were collected in Santiago Huauclilla, Oaxaca, in July 2014. This region is located at the parallels $17^{\circ} 25^{\prime}$ and $17^{\circ} 34^{\prime}$ latitude north and meridians $96^{\circ} 56^{\prime}$ and $97^{\circ} 08^{\prime}$ longitude west, and at altitude between 1,200 and 2,700 $\mathrm{m}$ (INEGI 2010). A voucher specimen (Number 16360) was identified by Dra. Martha J. Martínez Gordillo and deposited in the IMSS Herbarium of CDMX, Mexico.
Preparation of the extracts. Organic extracts were obtained by maceration of $S$. circinata, dry and ground aerial parts at room temperature, three successive extractions each 24 $\mathrm{h}$ were done using solvents $(2.5 \mathrm{~L})$ in increased polarity (hexane, ethyl acetate, and methanol analytical grade purchased in Tecsiquim, SA de CV, Mexico). Solvent excess was completely retired by evaporation in a rotoevaporator RII (Büchi Labortechnik AG, Switzerland) to obtain a final yield of the crude extracts (Figure 1). To identify chemical compounds involved in the pharmacological activity of $S$. circinata, samples of the crude extracts $(3 \mathrm{mg})$ were subjected to a high-performance liquid chromatographic (HPLCDAD) analysis. Since the hexane extract was obtained in a less yield than the ethyl acetate and methanol extracts (Figure 1), only these two were fractionated to isolate individual pure compounds (Figure 1).

Aqueous extract of $S$. circinata dried aerial parts was obtained by pulverizing $50 \mathrm{~g}$ of plant material and boiled in $500 \mathrm{~mL}$ of distilled water for $10 \mathrm{~min}$. Afterwards, the liquid was filtered at room temperature and then frozen in liquid nitrogen to be lyophilized (HETO FD3, Heto-Holten A/S, Denmark) to obtain a total yield of $10.6 \mathrm{~g}$.

High performance liquid chromatography (HPLC-DAD). Bioactive constituents of $S$. circinata were determined and quantified using a HPLC apparatus Agilent Technologies, series 1100 equipped with a diode array detector. A sample of each extract ( $3 \mathrm{mg})$ was dissolved in methanol (1 mL, HPLC grade from J.T.Baker, USA) and filtered into Acrodisc ${ }^{\circledR}$ syringe filters Nylon membrane, diameter $25 \mathrm{~mm}$, pore size $0.45 \mu \mathrm{m}$ to inject $15 \mu \mathrm{L}$ of each solution.

For identification and quantification of terpenes, a Zorbax Eclipse XDB-C 8 column $(125 \times 4.0 \mathrm{~mm}$ diameter and a 5 $\mu \mathrm{m}$ particle size) was used with a mobile phase of acetonitrile (MeCN, HPLC grade from J.T. Baker, USA)/water, 80:20 with a flow rate of $1 \mathrm{~mL} / \mathrm{min}$ and temperature at $40{ }^{\circ} \mathrm{C}$. Equipment was calibrated at a wavelength of 215 and 220 $\mathrm{nm}$ in a running time of $21 \mathrm{~min}$. Standard curves of calibration were built with five concentrations from 0.037 to 1.29 $\mu \mathrm{g}$ of standard terpenoids and amarisolide (99\% purity, determined by HPLC-DAD) obtained from $S$. circinata in this study. Other standards showing purity from 90 to $99 \%$ were ursolic acid, oleanolic acid, $\alpha$ - and $\beta$-amyrin, and $\beta$-sitosterol purchased at Sigma-Aldrich (St. Louis Mo. USA). Interpolation was done with the ChemStation program, Agilent Tech version B.02.01.

For identification and quantification of phenolic acids, a Nucleosil 100 A column $(125 \times 4.0 \mathrm{~mm}$ of diameter and a 5 $\mu \mathrm{m}$ particle size). Mobile phase has a flow rate of $1 \mathrm{~mL} / \mathrm{min}$ with a gradient of water at $\mathrm{pH} 2.5$ using trifluoroacetic acid/ MeCN: 0-10 min, $85 \%$ water: $15 \% \mathrm{MeCN} ; 10-20 \min , 65 \%$ 


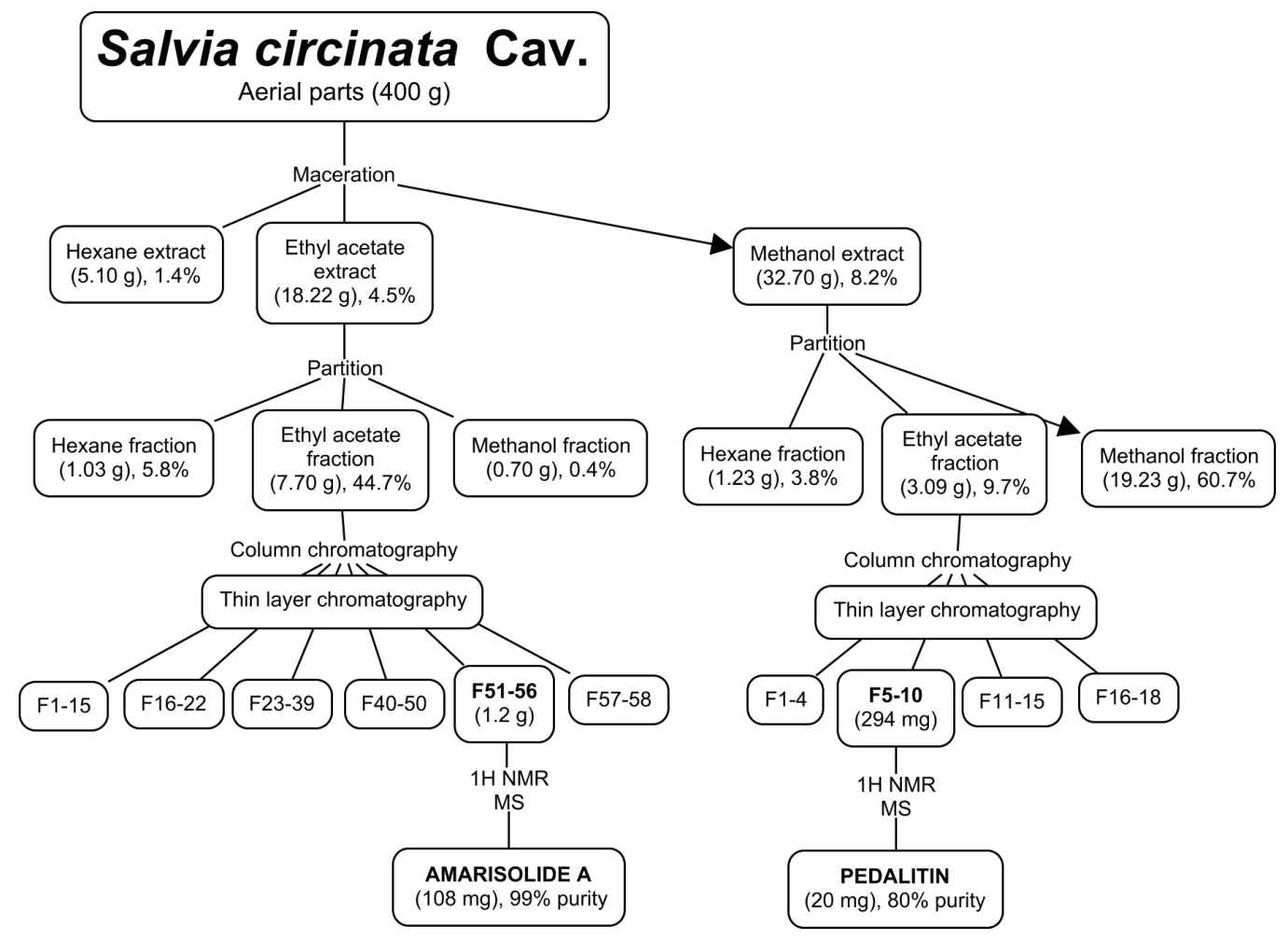

Figure 1. Diagram showing chromatographical fractionation of the $S$. circinata extracts to isolate pure compounds.

water: $35 \% \mathrm{MeCN}$; 20-23 min, $65 \%$ water: $35 \% \mathrm{MeCN}$ at $30{ }^{\circ} \mathrm{C}$. The wavelength was fixed at $280 \mathrm{~nm}$ in a running time of $23 \mathrm{~min}$. Standards of phenolic acids were chlorogenic, caffeic, ferulic, gallic, syringic, and vainillinic (purity from 90 to 99 \%, Sigma-Aldrich, St. Louis Mo. USA).

For flavonoids identification and quantification, a Hypersil ODS C18 column $(125 \times 4 \mathrm{~mm}$ diameter and at $5 \mu \mathrm{m}$ particle size) was used with a mobile phase flow rate $1 \mathrm{~mL} / \mathrm{min}$. The gradient consisted in water at $\mathrm{pH} 2.5$ and trifluoroacetic acid (Sigma-Aldrich, St. Louis Mo. USA)/MeCN 0-10 min, $85 \%$ water: $15 \% \mathrm{MeCN}$; $20 \mathrm{~min}, 65 \%$ water: $35 \% \mathrm{MeCN}$; 25 min, $65 \%$ water: $35 \% \mathrm{MeCN}$ at $30{ }^{\circ} \mathrm{C}$. Equipment was calibrated for detection at a wavelength of 254,316 , and 365 $\mathrm{nm}$ with a running time of $25 \mathrm{~min}$. Standards of flavonoids like kaempferol, quercetin, rutin, luteolin, naringin, naringenin, phloretin and phlorizin were purchased by Sigma-Aldrich (Purity from 90 to $99 \%$, St. Louis Mo. USA). Pedalitin ( $80 \%$ purity, determined by HPLC-DAD) was isolated and purified from the methanol extract of this study.

Fractionation of the organic extracts. The ethyl acetate (17.2 g) and methanol $(31.7 \mathrm{~g})$ extracts were partitioned using a chromatographic column packed with silica gel (Macherey-Nagel). The elution program started with hexane, to be continued with ethyl acetate, and finally methanol. The ethyl acetate fraction was separated on silica gel column chromatography in a proportion of $1: 15$, extract-eluent. The elution started with hexane followed by using a gradient of increasing polarity of hexane-ethyl acetate $(9: 1,8: 2,7: 3$, $6: 4,5: 5,4: 6,3: 7,2: 8,1: 9)$, ethyl acetate (100\%), ethyl acetate-methanol mixture $(9: 1,8: 2,7: 3)$, and finally methanol. A total of 58 subfractions $(100 \mathrm{~mL}$ each) were collected and then grouped by similarity according to their profiles acquired by thin layer chromatography (TLC) (Figure 1). From subfractions 51-56 eluted with ethyl acetate-methanol $8: 2$ and 7:3 was obtained compound 1, which was crystallized from methanol-acetone and analyzed trough ESIMS, ${ }^{1} \mathrm{H}$ and ${ }^{13} \mathrm{C}$ NMR. Identification of 1 was determined by comparision of its spectroscopic data with those described for amarisolide A, which were the same. Allowed purifying by crystallization a pure compound (m.p. $206{ }^{\circ} \mathrm{C}$, Fisher Johns equipment) that was analyzed by ESIMS in positive mode with a Cap LC coupled MicromassVR Q-ToF Ultima ESI system (Waters Corp., Milford, MA), as well as ${ }^{1} \mathrm{H}$ NMR and ${ }^{13} \mathrm{C}$ NMR analysis (Bruker, Avance DPX400). The NMR signals matched with that previous reported for this compound preliminary isolated from $S$. amarissima (Maldonado et al. 1996, Flores-Bocanegra et al. 2017).

Amarisolide A (1, yield $108 \mathrm{mg})$ : white powder, $\mathrm{mp} 206^{\circ} \mathrm{C}$; ${ }^{1} \mathrm{H}$ NMR (400 MHz, CD $\left.\mathrm{OD}\right) \delta=7.40(t, J=1.4 \mathrm{~Hz}, 1 \mathrm{H}$, $\mathrm{H}-15), 7.36(s, 1 \mathrm{H}, \mathrm{H}-16), 7.01(d, J=6.5 \mathrm{~Hz}, 1 \mathrm{H}, \mathrm{H}-3), 6.25$ $(d d, J=1.4,0.8 \mathrm{~Hz}, 1 \mathrm{H}, \mathrm{H}-14), 4.62(m, 1 \mathrm{H}, \mathrm{H}-2), 4.56(d$, $\left.J=7.8 \mathrm{~Hz}, 1 \mathrm{H}, \mathrm{H}-1^{\prime}\right), 4.41$ ( $\left.d, J=8.0 \mathrm{~Hz}, 1 \mathrm{H}, \mathrm{H}-19 \mathrm{a}\right), 4.07$ $(d d, J=8.0,2.0 \mathrm{~Hz}, 1 \mathrm{H}, \mathrm{H}-19 \mathrm{~b}), 3.95$ (dd, $J=11.0,4.2 \mathrm{~Hz}$, $1 \mathrm{H}, \mathrm{H}-6 \mathrm{a}$ '), 3.78 (dd, $J=11.3,3.2 \mathrm{~Hz}, 1 \mathrm{H}, \mathrm{H}-6 \mathrm{~b}$ '), $3.50(t$, $\left.J=8.5 \mathrm{~Hz}, 1 \mathrm{H}, \mathrm{H}-3^{\prime}\right), 3.43$ ( $t, J=9.0 \mathrm{~Hz}, 1 \mathrm{H}, \mathrm{H}-4$ '), 3.35 
( $\left.m, 1 \mathrm{H}, \mathrm{H}-5^{\prime}\right), 3.25$ ( $m, 1 \mathrm{H}, \mathrm{H}-2^{\prime}$ ), 2.68 ( $\left.m, 1 \mathrm{H}, \mathrm{H}-12 \mathrm{a}\right), 2.45$ $(d, J=13.0 \mathrm{~Hz}, 1 \mathrm{H}, \mathrm{H}-10), 2.37$ ( $t d, J=13.8,4.8 \mathrm{~Hz}, 1 \mathrm{H}$, H-12b), 2.09 ( $d, J=13.0 \mathrm{~Hz}, 1 \mathrm{H}, \mathrm{H}-1 \beta), 1.94(d, J=11.5$ $\mathrm{Hz}, 1 \mathrm{H}, \mathrm{H}-6 \alpha), 1.87$ ( $m, 1 \mathrm{H}, \mathrm{H}-8), 1.70-1.60$ ( $m, 2 \mathrm{H}, \mathrm{H}-7 \beta$ and $\mathrm{H}-11 \mathrm{a}), 1.54-1.50(m, 2 \mathrm{H}, \mathrm{H}-7 \alpha$ and $\mathrm{H}-11 \mathrm{~b}), 1.35(t, J$ $=12.0 \mathrm{~Hz}, 1 \mathrm{H}, \mathrm{H}-6 \beta), 1.31(m, 1 \mathrm{H}, \mathrm{H}-1 \alpha), 0.85\left(\mathrm{~s}, \mathrm{H}_{3}-17\right)$, $0.65\left(\mathrm{~s}, \mathrm{H}_{3}-20\right) ;{ }^{13} \mathrm{C}$ NMR $\left(100 \mathrm{MHz}, \mathrm{CD}_{3} \mathrm{OD}\right) \delta_{\mathrm{C}} 172.2(\mathrm{C}-$ 18), 142.5 (C-15), 147.2 (C-4), 139.5 (C-16), 132.6 (C-3), 126.4 (C-13), 112.8 (C-14), 103.5 (C-1'), 78.6 (C-3'), 77.1 (C-5'), 76.1 (C-2'), 74.2 (C-19), 72.9 (C-2), 70.9 (C-4'), 63.3 (C-6'), 47.5 (C-5), 40.2 (C-10), 39.5 (C-9), 38.9 (C-11), 38.2 (C-8), 36.1 (C-6), 29.2 (C-1), 28.2 (C-7), 19.1 (C-12), 16.9 (C-17), 18.6 (C-20); ESIMS: $m / z 493[\mathrm{M}+\mathrm{H}]^{+}, 475[\mathrm{M}+$ $\left.\mathrm{H}-\mathrm{H}_{2} \mathrm{O}\right]^{+}\left(\mathrm{C}_{26} \mathrm{H}_{36} \mathrm{O}_{9}\right)$.

Constituents from ethyl acetate fraction obtained from the methanol extract by partition; were separated by column chromatography eluted with mixtures hexane-acetone (5:5, $4: 6,3: 7,2: 8)$, acetone, and acetone-methanol 8:2. A total of 18 subfractions $(100 \mathrm{~mL})$ were obtained and grouped in 4 pools (Figure 1). Fraction eluted with hexane-acetone (3:7) gave a pale-yellow solid (m.p. $300^{\circ} \mathrm{C}$ ), and was analyzed by ${ }^{1} \mathrm{H}$ and ${ }^{13} \mathrm{C} \mathrm{NMR}$, and ESIMS. This compound was identified as pedalitin by comparison of their spectroscopic data with literature values (Maldonado et al. 1996, Flores-Bocanegra et al. 2017).

Pedalitin (11, yield $20 \mathrm{mg})$ : pale yellow powder, mp 300 ${ }^{\circ} \mathrm{C}$; ${ }^{1} \mathrm{H}$ NMR (400 MHz, DMSO- $\left.d_{6}\right), \delta=7.40$ (m, 2H, H-2' and H-6'), 6.91(d, $\left.J=8.0 \mathrm{~Hz}, 1 \mathrm{H}, \mathrm{H}-3^{\prime}\right), 6.80$ (s, 1H, H-3), 6.60 (s, 1H, H-8), 3.99 (s, 3H, $\left.-\mathrm{OCH}_{3}\right) .{ }^{13} \mathrm{C} \mathrm{NMR}(100 \mathrm{MHz}$, DMSO- $\left.d_{6}\right) \delta=183.3$ (C-4), 165.5 (C-2), 154.9 (C-7), 152.0 (C-9), 151.2 (C-5), 150.2 (C-4'), 146.5 (C-3'), 131.0 (C-6), 123.0 (C-1'), 119.9 (C-6'), 116.4 (C-5'), 113.9 (C-2'), 106.2 (C-10), 103.5 (C-3), $91.5(\mathrm{C}-8), 56.1\left(-\mathrm{OCH}_{3}\right)$. ESIMS: $m / z$ $317[\mathrm{M}+\mathrm{H}]^{+}$.

Animals. Male mice CD1 (25-30 g) available from "Facultad de Medicina, Universidad Nacional Autónoma de México" were used in this study. The animals were kept at constant room temperature $\left(22 \pm 1{ }^{\circ} \mathrm{C}\right)$ and maintained in a $12 \mathrm{~h} \mathrm{light/}$ dark cycle. The animals were fed ad libitum with standard feed and water. Experiments were carried out in accordance with local (Project NC12.3280.0) and national (NOM-062ZOO-1999) Ethical Committee Guidelines, as well as international (approved by the Institutional Animal Care and Use Committee based on US National Institutes of Health publication No. 85-23, revised 1985), regarding the care and use of animals for experimental procedures. For each treatment the animals were separated into groups of at least six mice. Each animal was tested once.

Drugs and reactives. Hexanic extract was resuspended in the vehicle $[0.5 \%$ tween 80 in saline solution (s.s.)]. Ethyl acetate, methanol, and aqueous extracts, as well as the reference drug Ketorolaco (SupraDol®), were dissolved in s.s. All treatments were administrated by intraperitoneal (i.p.) way in a volume of $10 \mathrm{~mL} / \mathrm{kg}$. Acetic acid (Baker) diluted at $1 \%$ was used as nociceptive agent. Drugs were freshly prepared on the day of the experiments.
Acute toxicity. Mice receiving the acute administration of the methanol and aqueous extracts at a maximal dosage of 2,000 $\mathrm{mg} / \mathrm{kg}$ i.p. allowed by OECD (2001) were observed for 14 days to register toxicological manifestations such as: loss of the consciousness, ataxia or respiratory depression, as well as possible death. At the end of the observation period of 14 days, surviving mice were euthanized to analyze macroscopically possible tissue alteration.

Nociceptive test (writhing). To build dose-response curves, all the extracts and pure bioactive compounds (1 and 11) were tested in independent groups at doses of $1,10,30,100$ and $300 \mathrm{mg} / \mathrm{kg}$. The antinociceptive activity was evaluated $30 \mathrm{~min}$ after their administration. The test consisted in the induction of an exaggerated extension of the abdomen combined with the outstretching of the hind limbs as previously reported (Collier et al. 1968). This nociceptive behavior was induced after i.p. administration of $10 \mathrm{~mL} / \mathrm{kg}$ of diluted acetic acid solution at $1 \%$. The number of writhes was immediately counted each $5 \mathrm{~min}$ for a total period of $30 \mathrm{~min}$ after the injection of the nociceptive agent (Viana et al. 2003).

Statistical analysis. The area under the curve (AUC) values were calculated from the respective temporal course curves obtained in the nociceptive behavior assays using the trapezoidal rule and they were considered as an expression of the nociceptive behavior in the writhing test. Data are expressed as the mean \pm standard error of the mean (SEM) of 6 animals. The statistical analysis was performed using oneway ANOVA followed by Dunnett's post hoc test. Graphpad Prism ${ }^{\circledR}$ version 6.0 for Windows (Graphpad Software, San Diego, CA, USA). A $P<0.05$ was considered statistically significant.

\section{Results}

Phytochemical analysis. According to the phytochemical analysis using several chromatographic techniques, the presence of possible bioactive metabolites was obtained as follows:

Terpenoids.- $S$. circinata showed five terpenoids in the hexane and ethyl acetate extracts: amarisolide A (1) (Figure 2 ), ursolic acid (2), oleanolic acid (3), $\alpha$-amyrin (4), and $\beta$ - sitosterol (5) (Table 1); as well as in the methanol extract with exception of 4 . The most abundant terpenoids in the hexane extract from major to lower were 2, 3, and 1; and

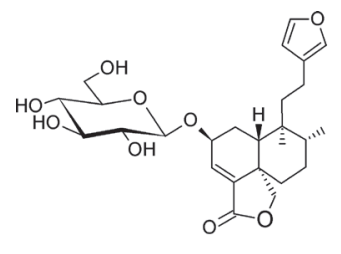

1

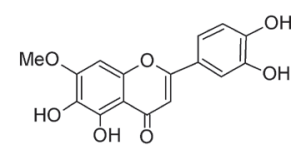

11
Figure 2. Structure of amarisolide A (1) and pedalitin (11). 
Antinociceptive effects of Salvia circinata and bioactive compounds

Table 1. Analysis of terpenoids, phenolic acids and flavonoids obtained from Salvia circinata aerial parts

\begin{tabular}{|c|c|c|c|c|c|c|}
\hline $\begin{array}{l}\text { Peak } \\
\text { No. }\end{array}$ & Compound & $\begin{array}{l}\text { Retention } \\
\text { time (min) }\end{array}$ & $\begin{array}{l}\text { Hexane } \\
(\mu \mathrm{g} / \mathrm{mg})\end{array}$ & $\begin{array}{l}\text { Ethyl acetate } \\
(\mu \mathrm{g} / \mathrm{mg})\end{array}$ & $\begin{array}{l}\text { Methanol } \\
(\mu \mathrm{g} / \mathrm{mg})\end{array}$ & $\begin{array}{r}\text { Aqueous } \\
\text { ( } \mu \mathrm{g} / \mathrm{mg})\end{array}$ \\
\hline & Terpenoids & & & & & \\
\hline 1 & Amarisolide A & 1.69 & 55.33 & 558.16 & 255.33 & 182.60 \\
\hline 2 & Ursolic acid & 2.73 & 96.33 & 250.05 & 12.76 & 7.35 \\
\hline 3 & Oleanolic acid & 4.65 & 67.00 & 69.23 & 197.83 & n.d. \\
\hline 4 & $\alpha$-amyrin & 5.76 & 22.66 & 62.60 & n.d. & n.d. \\
\hline 5 & $\beta$-sitosterol & 18.79 & 3.86 & 31.66 & 40.30 & 1.02 \\
\hline $\begin{array}{l}6 \\
7 \\
8\end{array}$ & $\begin{array}{l}\text { Phenolic acids } \\
\text { Chlorogenic acid } \\
\text { Caffeic acid } \\
\text { Ferulic acid }\end{array}$ & $\begin{array}{l}4.97 \\
7.32 \\
10.20\end{array}$ & $\begin{array}{l}\text { n.d. } \\
\text { n.d. } \\
\text { n.d. }\end{array}$ & $\begin{array}{l}14.01 \\
0.43 \\
32.91\end{array}$ & $\begin{array}{l}40.39 \\
5.79 \\
12.26\end{array}$ & $\begin{array}{l}44.93 \\
5.96 \\
12.32\end{array}$ \\
\hline 8 & Flavonoids & & & & & \\
\hline 9 & Rutin & 4.94 & n.d. & n.d. & 18.33 & 21.43 \\
\hline 10 & Phlorizin & 6.98 & n.d. & n.d. & 27.28 & 10.39 \\
\hline 11 & Pedalitin & 10.20 & n.d. & n.d. & 134.06 & 5.16 \\
\hline 12 & Quercetin & 10.82 & n.d. & 23.33 & n.d. & n.d. \\
\hline 13 & Phloretin & 12.72 & n.d. & 8.24 & n.d. & n.d. \\
\hline
\end{tabular}

n.d. $=$ not detected.

in the ethyl acetate and methanol extracts was principal the terpenoid 1 (Table 1). In the case of the aqueous extract, the compounds identified were 1,2 and 5, with the compound 1 as the most abundant (Table 1); all they were corroborated in the HPLC-DAD chromatograms (Figure 3).

Phenolic acids.- Phenolic acids were identified as follows: ferulic acid (8) was majority in the ethyl acetate extract that showed also caffeic acid (7) and chlorogenic acid (6) (Table 1 and Figure 3). These three compounds were identified again in the aqueous and methanol extracts, where 6 was the most abundant in both (Table 1 and Figure 3).

Flavonoids.- Quercetin (12) and phloretin (13) were identified in the ethyl acetate extract; whereas rutin (9), phlorizin (10), and pedalitin (11) (Figure 2) were obtained in the methanol and aqueous extracts. The compound 11 was the most abundant flavonoid in the methanol extract and compound 9 in the aqueous extract as corroborated by HPLC-DAD analysis (Figure 3).

Pharmacological analysis. Regarding to the pharmacological evaluation, all the treatments including organic extracts (Figure 4A-4F), aqueous (Figure 5A, B) and individual pure compounds (1 and 11, Figure 5C-5F), significantly decreased $(P<0.05)$ the number of writhes from a dosage of $1 \mathrm{mg} / \mathrm{kg}$, except for the aqueous extract that produce its significant antinociceptive response after a dosage of $10 \mathrm{mg} / \mathrm{kg}$ (Figure $5 \mathrm{~A}, \mathrm{~B})$ in comparison to the group receiving vehicle. Antinociceptive response produced by extracts and the pure compounds resembled the effect of the reference drug ketorolac ( $1 \mathrm{mg} / \mathrm{kg})$, the pharmacological response was dose-dependent in the evaluation with the medium polar (ethyl acetate) and polar extracts (methanol and aqueous) (Figures 4 and 5).

Acute toxicity of the organic and aqueous extracts was calculated to be $>2,000 \mathrm{mg} / \mathrm{kg}$. Mice did not show weight loss during the 14-days observation period and it was not observed macroscopic tissue injury in those surviving sug- gesting that low toxicity might be expected in the use of this species to alleviate abdominal pain.

\section{Discussion}

The present study demonstrates for the first time that organic and aqueous extracts, as well as some isolated and purified compounds from Salvia circinata, reduce nociception in mice. The three organic extracts (hexane, ethyl acetate and methanol) of $S$. circinata showed a similar pharmacological profile in the antinociceptive responses in mice treated with a range of doses in a logarithmic increase from 1 to $300 \mathrm{mg} / \mathrm{kg}$ showing a dose-dependent effect in case of the ethyl acetate and methanol extracts, but not with the hexane extract and the pure compounds amarisolide A and pedalitin.

Compounds 1, 2, 3 and 5 were identified in all the organic extracts, as well as in the aqueous extract, with an exception of oleanolic acid. While, $\alpha$-amyrin was determined in the hexane and ethyl acetate extracts. In the case of amarisolide A, its presence was abundant mainly in the ethyl acetate and methanol extracts. Pharmacological antinociceptive activity for this terpenoids is lacking in literature; consequently, investigation about it is important to explore and describe. Recently, this terpenoid was isolated from aerial parts of $S$. circinata, and its antihyperglycemic activity was evaluated (Flores-Bocanegra et al. 2017). In the present study, the antinociceptive activity was tested using a model of abdominal pain in which it produced at least $50 \%$ inhibition from a minimal dose of $1 \mathrm{mg} / \mathrm{kg}$. The effect did not show increase by increasing doses and it was like that produced by different organic extracts even in those in which it was detected in greater abundance. It is possible that amarisolide $\mathrm{A}$ is one of the main bioactive metabolites responsible for the antinociceptive activity of this plant species. Nevertheless, there was detected other compounds that likely contribute to the 


\section{Terpenoids}
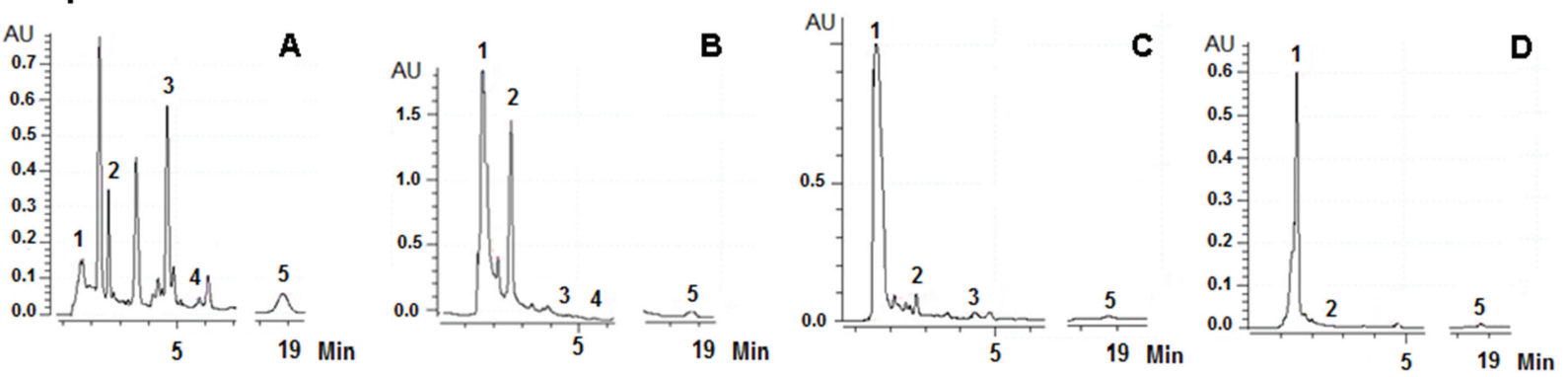

Phenolic acids
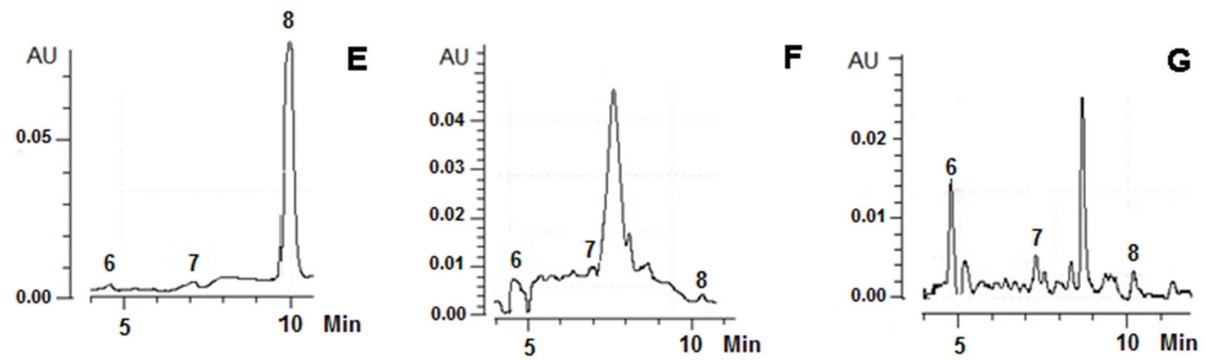

Flavonoids
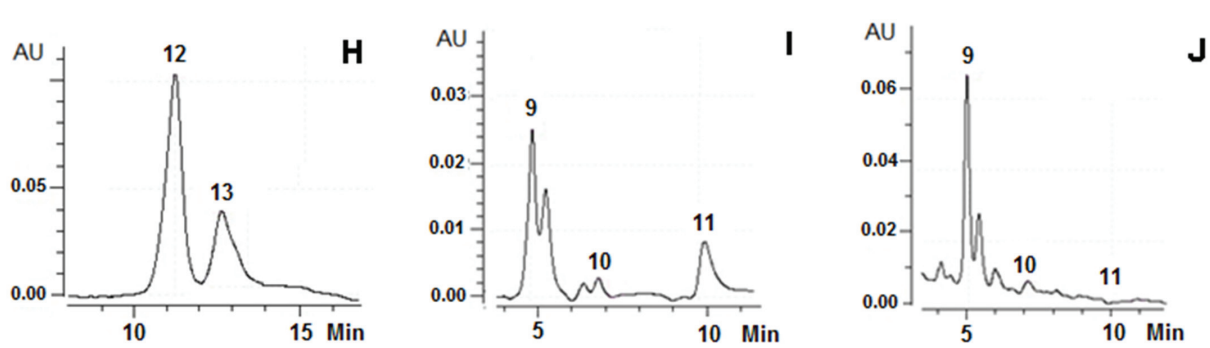

Figure 3. HPLC-DAD chromatograms of the $S$. circinata showing terpenoids, phenolic acids, and/or flavonoids as identified compounds in the hexane (A), ethyl acetate (B, E, and H), methanol (C, F, and I), and aqueous (D, G, and J) extracts. Amarisolide A (1), ursolic acid (2), oleanolic acid (3), $\alpha$-amyrin (4), $\beta$-sitosterol (5), chlorogenic acid (6), caffeic acid (7), ferulic acid (8), rutin (9), phlorizin (10), pedalitin (11), quercetin (12), phloretin (13).

final effect of the crude extracts. The mechanism of action of amarisolide A was not explored in this study; however, it was isolated from Salvia rubescens and reported as anti-inflammatory by inhibition of the elastase and myeloperoxidase enzymes (22 $\pm 4 \%$ and $38 \pm 10 \%$, respectively) at $100 \mu \mathrm{M}$ in a model of murine inflammation (Rodriguez et al. 2005).

Other terpenoids identified in S. circinata were the ursolic and oleanolic acids; these compounds have been already reported in S. officinalis due to their antinociceptive activity, which was observed at the dose of $30 \mathrm{mg} / \mathrm{kg}$, producing inhibition in the inflammatory phase of the formalin test, and antinociception in the mechanical allodynia induced by cinnamaldehyde possibly through TRPA1-receptors (Rodrigues et al. 2012). On the other hand, terpenoids both have been isolated as responsible bioactive metabolites of pharmacological antinociceptive effects of Rosmarinus officinalis (Martínez et al. 2012) and Agastache mexicana (Verano et al. 2013), showing dose-dependent effects with an $\mathrm{ED}_{50}=$ $1.6 \mathrm{mg} / \mathrm{kg}$ and $2.1 \mathrm{mg} / \mathrm{kg}$, respectively. A participation of cGMP pathway and serotonergic neurotransmission through $5-\mathrm{HT}_{1 \mathrm{~A}}$ receptors, as well as TRPV1 receptors were also considered in the antinociceptive responses of ursolic acid in the writhing and capsaicin tests in mice (Verano et al. 2013). In the case of oleanolic acid, its antinociceptive effects were mediated by an opioidergic and serotonergic, but not by adrenergic receptors, in glutamate-induced like pain (Park et al. 2013). Regarding $\beta$-sitosterol, its antinociceptive properties were responsible of the activity of Buddleja thyrsoides (Fialho et al. 2017) and Moringa oleifera at doses of 18,25 and $35 \mathrm{mg} / \mathrm{kg}$ significantly attenuated hyperalgesia and tactile allodynia in a neurophatic pain model (Raafat \& Hdaib 2017). Finally, $\alpha$-amyrin obtained in the hexane and ethyl acetate extracts is other possible responsible bioactive metabolite of $S$. circinata since it has been reported that alone or combined with $\beta$ - amyrin produces inhibition of pain like orofacial induced by formalin and capsaicin (Holanda-Pinto et al. 2008). Its antinociceptive effects have been associated with inhibition of COX-2 enzyme and diminution in the proinflammatory cytokines (Medeiros et al. 2007). The effects of the extracts were observed in a dose-dependent manner when fenolic acids and flavonoids were present together with terpenoids. These results suggest likely synergistic interac- 
A

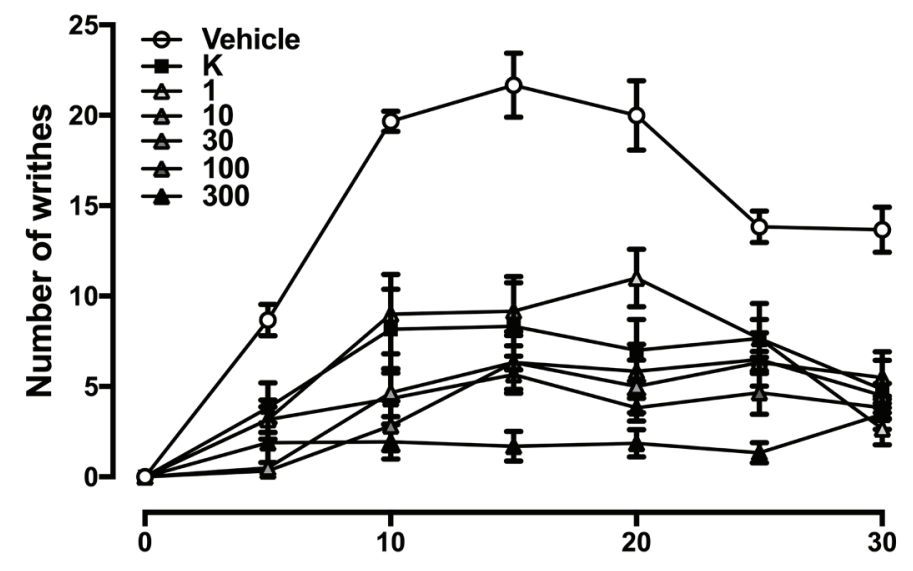

C

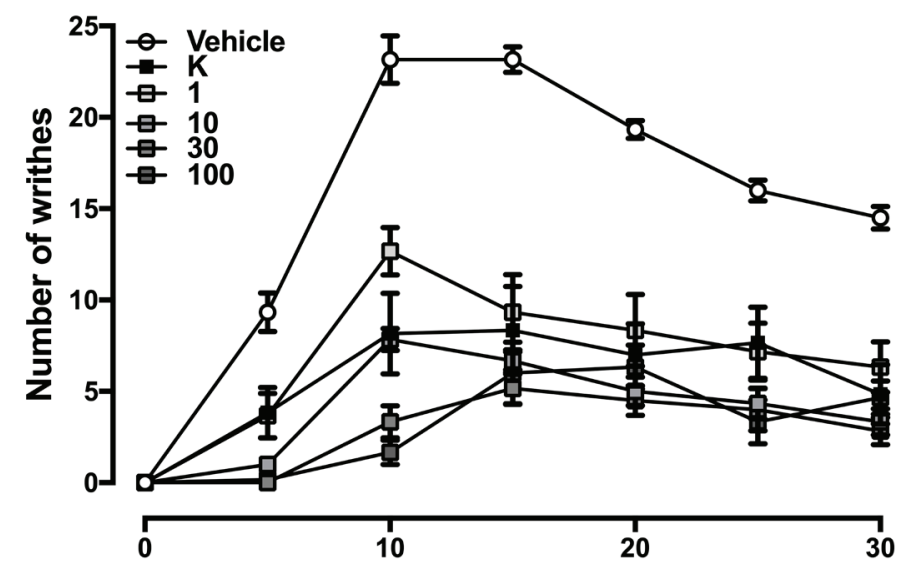

E

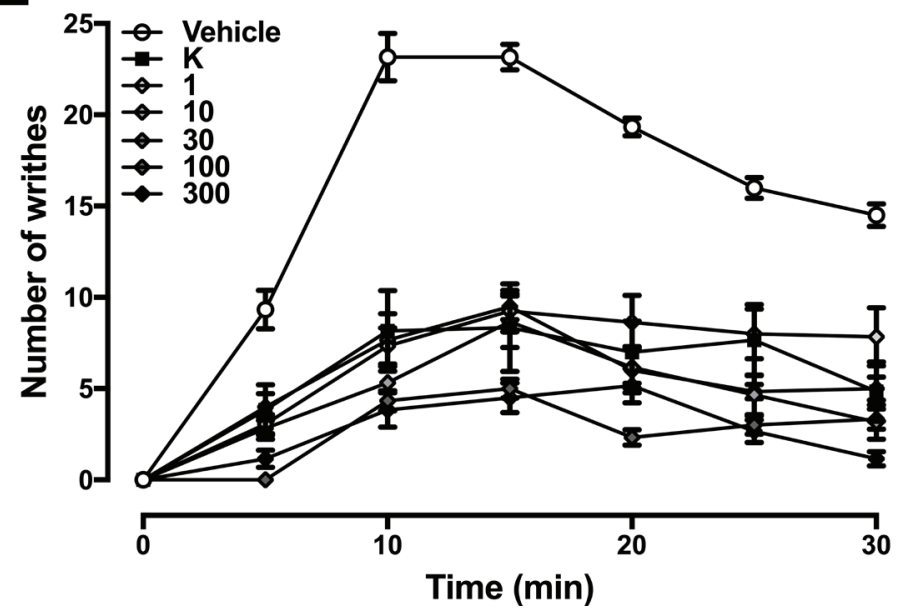

B

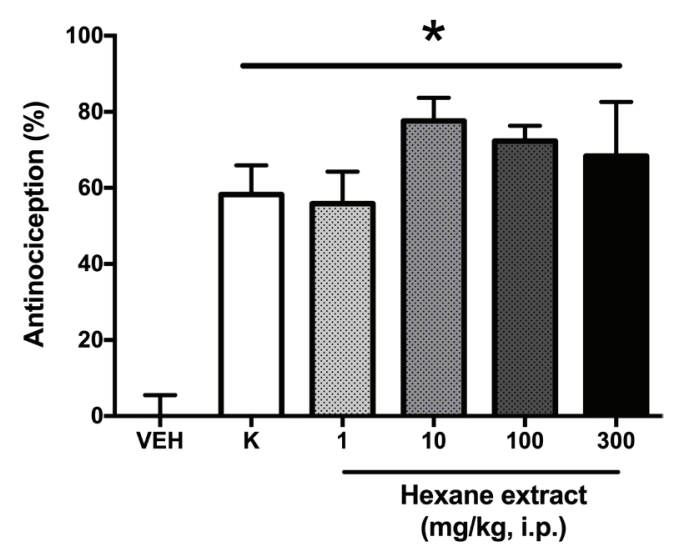

D

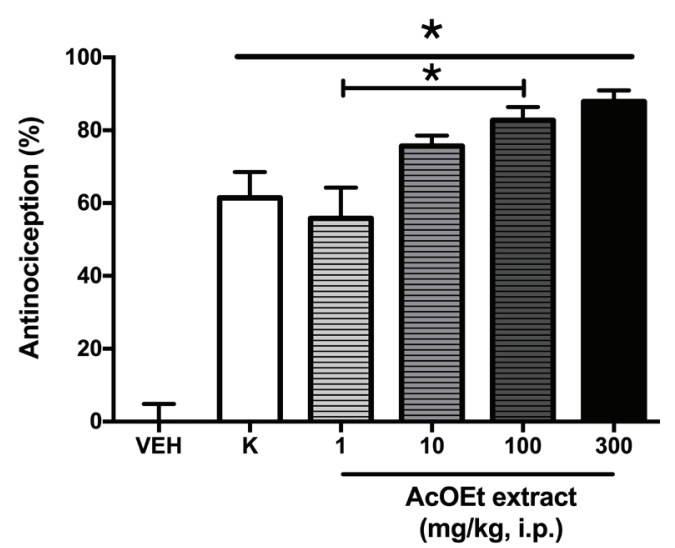

$\mathbf{F}$

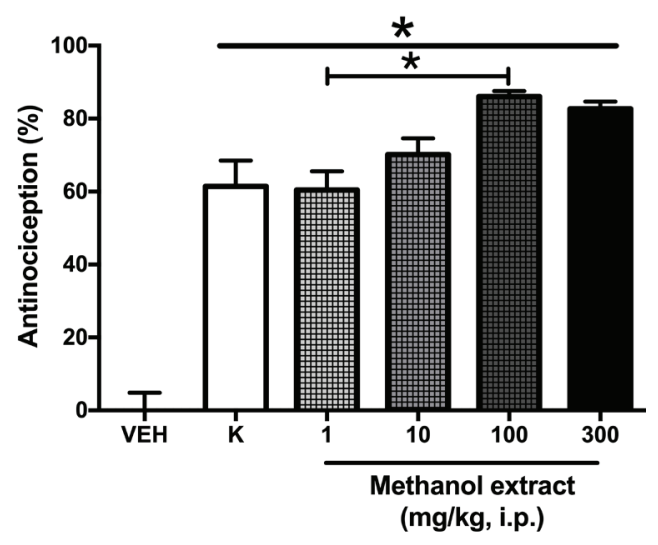

Figure 4. Temporal course curves (TCC) of the nociceptive activity induced by $1 \%$ acetic acid in the presence of the vehicle, ketorolac (reference drug) and the crude organic extracts hexane (A), ethyl acetate (C), and methanol (E). The corresponding antinociceptive activity expressed as percentage from the TCC is indicated in the panels (B, D, and F, respectively). Each point and bars represent the mean \pm standard error of 6 mice. One-way ANOVA followed by Dunnett's test, $* P<0.05$ was considered significant. 
A

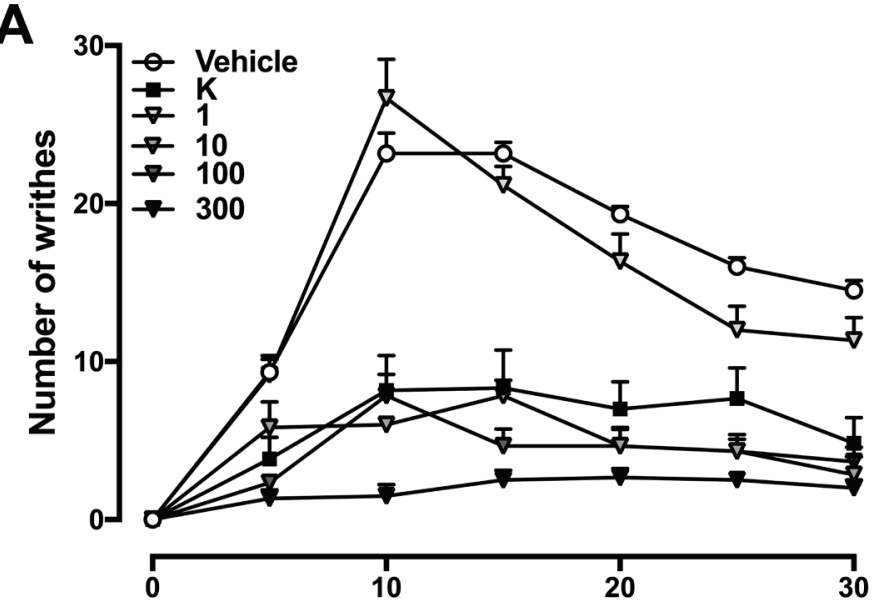

C

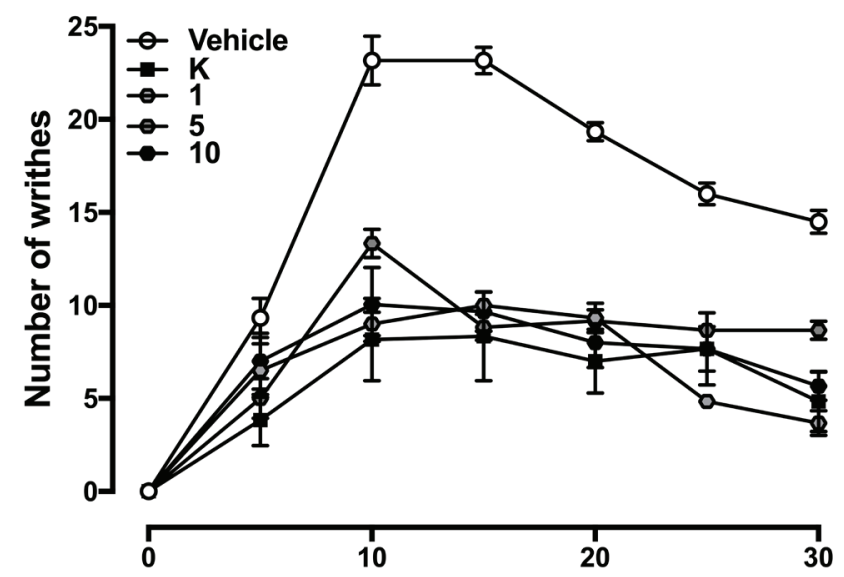

$\mathbf{E}$

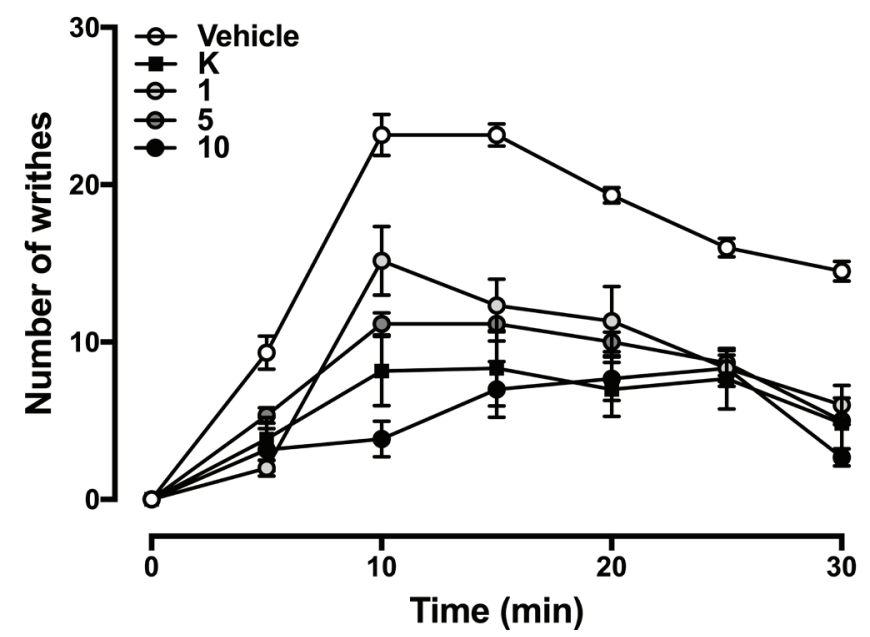

B

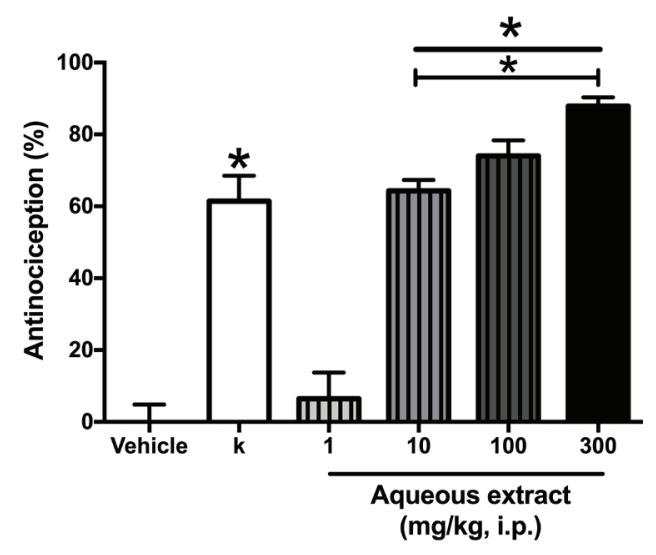

D

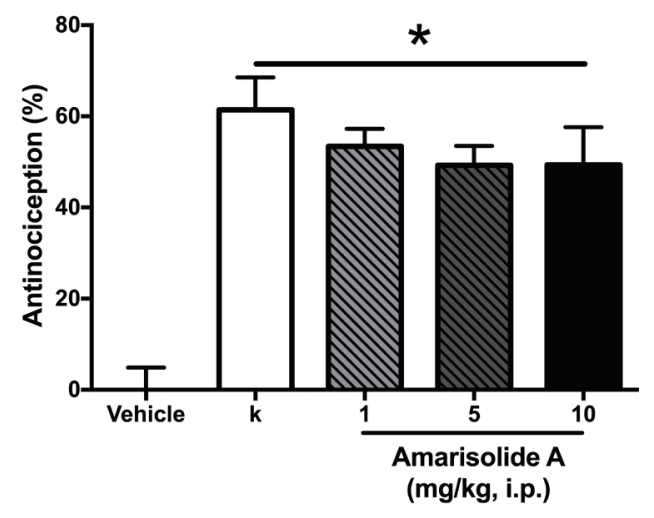

$\mathbf{F}$

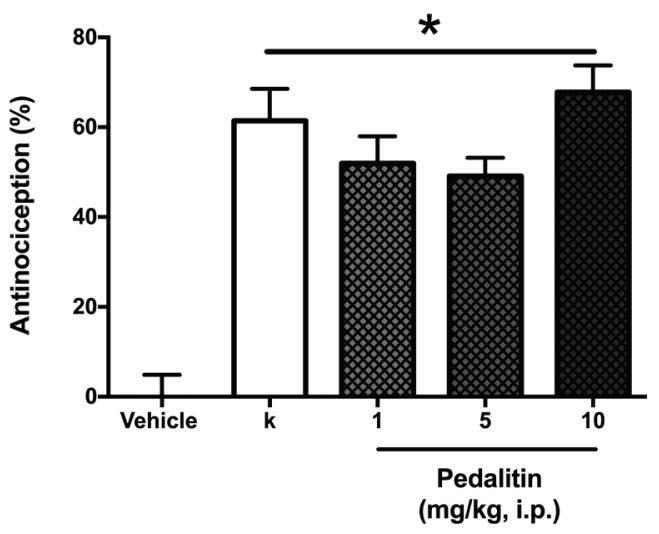

Figure 5. Temporal course curves (TCC) of the nociceptive activity induced by $1 \%$ acetic acid in the presence of the vehicle, ketorolac (reference drug) and the aqueous (A) and individual pure compounds amarisolide A (C) and pedalitin (E). The corresponding antinociceptive activity in percentage obtained from the TCC is indicated in the panels (B, D, and F, respectively). Each point and bars represent the mean \pm standard error of 6 mice. One-way ANOVA followed by Dunnett's test, ${ }^{*} P<0.05$ was considered significant. 
tions in this plant that will be interesting to study in a future investigation.

This is the first time that antinociceptive activity is evidenced for $S$. circinata in agreement and reinforcing this activity already reported for other species of Salvia genus. For example, the $S$. wiedemannii chloroform extract from its aerial parts produced antinociceptive effects in the tail-flick and acetic acid-induced writhing tests in mice (Ustun \& Sezik 2011); the $S$. officinalis hexane and chloroform extracts inhibited in a dose-dependent fashion the croton oil-induced ear oedema in mice (Baricevic et al. 2001), as well as in the aqueous and butanol leaf extracts in the hot plate and formalin tests in rats (Qnais et al. 2010). S. hypoleuca and S. limbata reported antinociceptive activity in the methanol and aqueous extracts of the aerial parts using the hot plate model in mice (Karami et al. 2013). Nevertheless, S. circinata demonstrated better antinociceptive potency in comparison to these species from the same genus, since we observed significant and maximal response from 1 to $10 \mathrm{mg} / \mathrm{kg}$, i.p. in comparison to the significant response observed at $500 \mathrm{mg} / \mathrm{kg}$, i.p. in the case of $S$. wiedemannii in the same nociceptive test (Ustun \& Sezik 2011). Other species has demonstrated antinociceptive effect in other tests using higher dosage; for example: Salvia hypoleuca and S. limbata using a minimal dose of $100 \mathrm{mg} / \mathrm{kg}$ and a maximal of $1,500 \mathrm{mg} / \mathrm{kg}$, i.p. (Karami et al. 2013). In contrast, there are species from this genus without antinociceptive efficacy as reported for $S$. halophila and $S$. virgata in the writhing test (Küpeli et al. 2008). This difference is probably associated with the chemical composition. According to the phytochemical background analyzed in S. circinata in this investigation, mainly the identified terpenoid content, might play an important role in the antinociceptive activity of this genus species suggesting its potential for the pain therapy and reinforcing the medical traditional use of this plant.

The chromatographic fractionation of the methanol extract allowed identify and purify also some flavonoids like pedalitin, which was the most abundant compound showing significant antinociceptive effects from a dose of $1 \mathrm{mg} / \mathrm{kg}$. This pharmacological activity might be associated to the inhibition property on the mediators like NO, TNF- $\alpha$ and IL-12 production (Rao et al. 2009). Other biological activities of pedalitin are the antioxidant effects by inhibition of myeloperoxidase and as a scavenger of free radicals (Fernandes et al. 2008), as well as antihyperglycemic (Flores-Bocanegra et al. 2017).

Regarding to $S$. circinata aqueous extract, this was less active than the organics extracts since its significant response was observed at $10 \mathrm{mg} / \mathrm{kg}$ in comparison to $1 \mathrm{mg} / \mathrm{kg}$, respectively. The most abundant chemical metabolites were amarisolide A, chlorogenic acid, and rutin. Chlorogenic acid has been involved in the antinociceptive effects of other species with this property (Küpeli et al. 2012, Martínez-González et al. 2016). In case of rutin, this flavonoid glycoside possesses antinociceptive properties mediated by central opioidergic neurotransmission (Selvaraj et al. 2014, HernandezLeon et al. 2016). This flavonoid has been even combined with a clinical analgesic to improve the efficacy against pain (Alonso-Castro et al. 2017).
The acute toxicity evaluation in vivo allowed to calculate a $\mathrm{LD}_{50}>2,000 \mathrm{mg} / \mathrm{kg}$, i.p., for all the aqueous and organic extracts of $S$. circinata, at least at a maximal dosage recommended in the normativity of the OECD (2001), placing these extracts in category 5 of the globally harmonized system of classification and labeling of non-toxic chemical products. These results are consistent with previous data conducted in the aerial parts of the same species using $5 \mathrm{~g} / \mathrm{kg}$, p.o. (Flores-Bocanegra et al. 2017) and in other Salvia species like in $S$. leriifolia seeds aqueous extract determined as $\mathrm{LD}_{50}$ $=19.5 \mathrm{~g} / \mathrm{kg}$, i.p. in mice (Hosseinzadeh et al. 2003) and in $S$. officinalis leaves hydroalcoholic extract with $\mathrm{LD}_{50}=44.75$ $\mathrm{g} / \mathrm{kg}$, p.o. (Rodrigues et al. 2012).

In conclusion, the present investigation gives pharmacological evidence of the potential use of $S$. circinata in the pain therapy due to the presence of diversity of bioactive compounds like terpenoids, phenolic acids, and flavonoids to validate the use of this species in the Mexican Traditional Medicine reported by the inhabitants of Santiago Huauclilla, Oaxaca, Mexico.

\section{Acknowledgements}

This work was supported by PAPIIT-IN218418, CONACYT 256448/256454. The authors thanks to Enrique Pinzón Estrada, Ismael Torres Saldaña, Alberto Hernandez Leon, Lizeth M. Zavala-Ocampo, and Verónica Muñoz Ocotero for their technical assistance, as well as Marissa González for proofreading the manuscript.

\section{Literature cited}

Alonso-Castro AJ, Rangel-Velázquez JE, Isiordia-Espinoza MA, Villanueva-Solís LE, Aragon-Martinez OH, Zapata-Morales JR. 2017. Synergism between naproxen and rutin in a mouse model of visceral pain. Drug Development Research 78: 184188. DOI: https://doi.org/10.1002/ddr.21391

Baricevic D, Sosa S, Della Loggia R, Tubaro A, Simonovska B, Krasna A, Zupancic A. 2001. Topical anti-inflammatory activity of Salvia officinalis L. leaves: the relevance of ursolic acid. Journal of Ethnopharmacology 75: 125-132. DOI: https://doi.org/10.1016/S0378-8741(00)00396-2

Bautista E, Fragoso-Serrano M, Toscano RA, García-Peña MR, Ortega A. 2015. Teotihuacanin, a diterpene with an unusual spiro-10/6 system from Salvia amarissima with potent modulatoy activity of multidrug resistence in carcer cells. Organic Letters 17: 3280-3282.

DOI: https://doi.org/10.1021/acs.orglett.5b01320

Bautista E, Fragoso-Serrano M, Ortiz-Pastrana N, Toscano RA, Ortega A. 2016. Structural elucidation and evaluation of multidrug-resistance modulatory capability of amarissinins A-C, diterpenes derived from Salvia amarissima. Fitoterapia 114: 1-6. DOI: http://doi.org/10.1016/J.FITOTE.2016.08.007

Castro JCJ, Villa-Ruano N, Ramirez Garcia SA, Mosso GC. 2014. Medicinal use of antidiabetic plants in Oaxacan ethnobotanical tradition. Revista Cubana de Plantas Medicinales 19: 101-120.

Collier HO, Dinneen LC, Johnson C a, Schneider C. 1968. The 
abdominal constriction response and its suppression by analgesic drugs in the mouse. British Journal of Pharmacology and Chemotherapy 32: 295-310.

DOI: https://doi.org/10.1111/j.1476-5381.1968.tb00973.x

Fernandes DC, Regasini LO, Vellosa JCR, Pauletti PM, CastroGamboa I, Bolzani VS, Oliveira OMM, Silva DES. 2008. Myeloperoxidase Inhibitory and Radical Scavenging Activities of Flavones from Pterogyne nitens. Chemical and Pharmaceutical Bulletin 56: 723-726.

DOI: https://doi.org/10.1248/cpb.56.723

Fialho MFP, Brusco I, da Silva Brum E, Piana M, Boligon AA, Trevisan G, Oliveira SM. 2017. Buddleja thyrsoides Lam. crude extract presents antinociceptive effect on an arthritic pain model in mice. Biochemical Journal 474: 2993-3010. DOI: https://doi.org/10.1042/BCJ20170008

Flores-Bocanegra L, González-Andrade M, Bye R, Linares E, Mata R. 2017. a-glucosidase inhibitors from Salvia circinata. Journal of Natural Products 80: 1584-1593.

DOI: https://doi.org/10.1021/acs.jnatprod.7b00155

Fragoso-Serrano M, Ortiz-Pastrana N, Luna-Cruz N, Toscano RA, Alpuche-Solís AG, Ortega A, Bautista E. 2019. Amarisolide F, an acylated diterpenoid glucoside and related terpenoids from Salvia amarissima. Journal of Natural Product $\mathbf{8 2}$ : 631-635. DOI: https://doi.org/10.1021/acs.jnatprod.8b00565

Hernandez-Leon A, Fernández-Guasti A, González-Trujano ME. 2016. Rutin antinociception involves opioidergic mechanism and descending modulation of ventrolateral periaqueductal grey matter in rats. European Journal of Pain 20: 274-283. DOI: https://doi.org/10.1002/ejp.720

Holanda-Pinto SA, Pinto LM, Guedes MA, Cunha GM, Chaves MH, Santos FA, Rao VS. 2008. Antinoceptive effect of triterpenoid alpha,beta-amyrin in rats on orofacial pain induced by formalin and capsaicin. Phytomedicine 15: 630-634. DOI: https://doi.org/10.1016/j.phymed.2007.11.016

Hosseinzadeh H, Haddadkhodaparast MH, Arash AR. 2003. Antinociceptive, antiinflammatory and acute toxicity effects of Salvia leriifolia Benth. seed extract in mice and rats. Phytotherapy Research 17: 422-425.

DOI: https://doi.org/10.1002/ptr.1154

INEGI. 2010. Prontuario de información geográfica municipal de los Estados Unidos Mexicanos. Catalogo de localidades. $<$ http://www.microrregiones.gob.mx/catloc/contenido. aspx?refnac $=204630001>($ accessed April 10, 2017).

Karami M, Shamerani MM, Hossini E, Gohari AR, Ebrahimzadeh MA, Nosrati A. 2013. Antinociceptive activity and effect of methanol extracts of three Salvia spp. on withdrawal syndrome in mice. Advanced Pharmaceutical Bulletin 3: 457459. DOI: https://doi.org/10.5681/apb.2013.075

Küpeli AE, Göger F, Koşar M, Başer KHC. 2008. Phenolic composition and biological activities of Salvia halophila and Salvia virgata from Turkey. Food Chemistry 108: 942-949. DOI: https://doi.org/10.1016/j.foodchem.2007.11.071

Küpeli AE, Bahadır AO, Süntar I, Ergene B, Saltan ÇG. 2012. Ethnopharmacological evaluation of some Scorzonera species : in vivo anti-inflammatory and antinociceptive effects. Journal of Ethnopharmacology 140: 261-270.

DOI: https://doi.org/10.1016/j.jep.2012.01.015

Maldonado E, Cárdenas J, Bojórquez H, Escamilla EM, Ortega
A. 1996. Amarisolide, a neo-clerodane diterpene glycoside from Salvia amarissima. Phytochemistry 42: 1105-1108. DOI: https://doi.org/10.1016/0031-9422(96)00147-1

Martínez AL, González-Trujano ME, Chávez M, Pellicer F. 2012. Antinociceptive effectiveness of triterpenes from rosemary in visceral nociception. Journal of Ethnopharmacology 142: 28-34. DOI: https://doi.org/10.1016/j.jep.2012.03.052

Martínez-González CL, Martínez L, Martínez-Ortiz EJ, González-Trujano ME, Déciga-Campos M, Ventura-Martínez R, Díaz-Reval I. 2016. Moringa oleifera, a species with potential analgesic and anti-inflammatory activities. Biomedicine \& Pharmacotherapy 87: 482-488.

DOI: https://doi.org/10.1016/J.BIOPHA.2016.12.107

Martínez-Gordillo M, Fragoso-Martínez I, García-Peña MR, Montiel O. 2013. Géneros de Lamiaceae de México, diversidad y endemismo. Revista Mexicana de Biodiversidad 84: 30-86. DOI: https://doi.org/10.7550/rmb.30158

Medeiros R, Otuki MF, Avellar MCW, Calixto JB. 2007. Mechanisms underlying the inhibitory actions of the pentacyclic triterpene alpha-amyrin in the mouse skin inflammation induced by phorbol ester 12-O-tetradecanoylphorbol-13-acetate. European Journal of Pharmacology 559: 227-235. DOI: https://doi.org/10.1016/j.ejphar.2006.12.005

Nambo CA. 2015. Etnobotánica de Santiago Huauclilla, Oaxaca y evaluación farmacológica de Zinnia peruviana. BSc. Thesis, Universidad Nacional Autonoma de México.

OECD. 2001. OECD guideline for testing of chemicals. Acute Oral Toxicity-Fixed Dose Procedure. Oecd. DOI: https://doi.org/10.1787/9789264070943-en

Park SH, Sim YB, Kang YJ, Kim SS, Kim CH, Kim SJ, Suh HW. 2013. Mechanisms involved in the antinociceptive effects of orally administered oleanolic acid in the mouse. Archives of Pharmacal Research 36: 905-911. DOI: https://doi.org/10.1007/s12272-013-0093-7

Qnais EY, Abu-Dieyeh M, Abdulla FA, Abdalla SS. 2010. The antinociceptive and anti-inflammatory effects of Salvia officinalis leaf aqueous and butanol extracts. Pharmaceutical Biology 48: 1149-1156.

DOI: https://doi.org/10.3109/13880200903530763

Raafat K, Hdaib F. 2017. Neuroprotective effects of Moringa oleifera: Bio-guided GC-MS identification of active compounds in diabetic neuropathic pain model. Chinese Journal of Integrative Medicine 2017: 1-10.

DOI: https://doi.org/10.1007/s11655-017-2758-4

Rao YK, Fang SH, Hsieh SC, Yeh TH, Tzeng YM. 2009. The constituents of Anisomeles indica and their anti-inflammatory activities. Journal of Ethnopharmacology 121: 292-296. DOI: https://doi.org/10.1016/J.JEP.2008.10.032

Rodriguez M, Vergel N, Ospina L, Calle J, Pizón R. 2005. Evaluación de actividades enzimáticas elastasa y mieloperoxidasa como marcadores de desgranulación leucocitaria en modelos de inflamación aguda. Revista Colombiana de Ciencias Químico-Farmacéuticas 34: 35-45.

Rodrigues MRA, Kanazawa LKS, das Neves TLM, da Silva CF, Horst H, Pizzolatti MG, Santos AR, Baggio CH, Werner MF. 2012. Antinociceptive and anti-inflammatory potential of extract and isolated compounds from the leaves of Salvia officinalis in mice. Journal of Ethnopharmacology 139: 519- 
526. DOI: https://doi.org/10.1016/j.jep.2011.11.042

Selvaraj G, Kaliamurthi S, Thirungnasambandam R, Vivekanandan L, Balasubramanian T. 2014. Anti-nociceptive effect in mice of thillai flavonoid rutin. Biomedical and Environmental Sciences 27: 295-299.

DOI: https://doi.org/10.3967/bes2014.052

Ustun O, Sezik E. 2011. Analgesic activity of Salvia Wiedemannii Boiss. used in Turkish folk medicine. Records of Natural Products 5: 328-331.

DOI: https://doi.org/10.1055/s-0031-1282811
Verano J, González-Trujano ME, Déciga-Campos M, VenturaMartínez R, Pellicer F. 2013. Ursolic acid from Agastache mexicana aerial parts produces antinociceptive activity involving TRPV1 receptors, cGMP and a serotonergic synergism. Pharmacology Biochemistry and Behavior 110: 255264. DOI: https://doi.org/10.1016/j.pbb.2013.07.020

Viana GSB, Bandeira MAM, Matos FJA. 2003. Analgesic and antiinflammatory effects of chalcones isolated from Myracrodruon urundeuva allemão. Phytomedicine 10: 189-195. DOI: https://doi.org/10.1078/094471103321659924

\section{Associated editor: Elihú Bautista}

Author Contributions: GFMP participated in the performance of experimental work and preparation of the manuscript. MEGT participated in the performance of nociceptive test, preparation and revision of the manuscript. MJMG and FABP participated in the collected and identified the plant material and revision of the manuscript. RSMC participated in the HPLC analysis and revision of the manuscript. ADG participated in the structure elucidation and revision of the manuscript. EAH participated in the isolation and purification of compounds, preparation and revision of the manuscript. 